\title{
Inspector Ahmed Kemal Effendi's Visit to Europe to Observe the Modern Education System (1850-1851)
}

\author{
Eyup Cucuk', Ayhan Dogan ${ }^{2}$ \\ ${ }^{1,2}$ Gaziantep Faculty of Education, Gaziantep University, Turkey
}

\begin{abstract}
Ahmed Kemal Effendi/Pasha (1808-1886) is a very important figure in terms of the policies and practices developed in the context of the modernization of the Ottoman education system in the Tanzimat Period. Between 1848-1854, he served as inspector general of the schools of the Empire. Accordingly, it was decided to deploy him to Europe for 10 months in order to increase and develop his already well-known skills and competencies based on the tasks he had already undertaken. The aim of this study was to examine the observations and investigations made by Ahmed Kemal Effendi in some European cities between August 1850 and April 1851 and to reveal its effects on the Ottoman education system. This research, which uses qualitative research methods and techniques, is designed as a descriptive historical study based on original and primary sources. The historical documents about the visits of Ahmed Kemal Effendi to some European cities were analysed through content analysis and descriptive analysis methods. As reflected in the findings of this research, Kemal Effendi traveled to Europe from August 1850 to April 1851 and made educational observations and inspections in the cities such as Paris, London, Brussels, Cologne, Berlin and Vienna. By transferring the knowledge and experiences he gained abroad to his country, he initiated significant practices towards the modernization of education in the Ottoman Empire. Kemal Effendi's course materials, purchased from Paris, began to be used in newly established secondary schools, called as Rüştiye. It can actually be considered as the first implementation of modernization in Ottoman educational technologies.
\end{abstract}

Keywords: Ottoman Empire, Ahmed Kemal Effendi, History of Education.

\section{Introduction}

Ahmed Kemal Effendi/Pasha (1808-1886) is a very important figure in terms of the policies and practices developed in the context of the modernization of the Ottoman education system in the Tanzimat Period. As one of the reformist intellectuals of this period, he was a bureaucrat who contributed many innovations especially in the field of education. Between 1848-1854, he served as inspector general of the schools of the Empire (inspecteur général des écoles de l'empire). Since the Ministry of Education had not been established in the Ottoman Empire at that time, he was appointed as the person exclusively responsible for all operations related to 


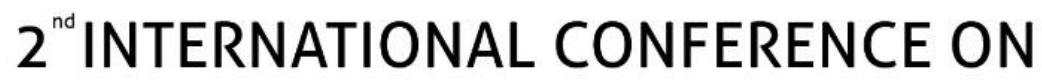 FUTURE OF TEACHING \& EDUCATION}

\section{Munich,Germany}

\section{6 - 8 December,2019}

the new and modern schools opened in the country ${ }^{1}$. Following his title of inspector general of public instruction, he made significant efforts for the successful establishment and structuring of the Ottoman education system and order. Moreover, it was believed that Kemal Effendi's developing and improving his knowledge and experience by learning the new developments in education in Europe would contribute greatly to both him and his country as the Minister of Education. Accordingly, it was decided to deploy him to Europe for 8 months in order to increase and develop his already well-known skills and competencies based on the tasks he had already undertaken ${ }^{2}$.

The aim of this study was to examine the observations and investigations made by Ahmed Kemal Effendi in some European cities between August 1850 and April 1851 and to reveal its effects on the Ottoman education system.

\section{Methods}

This research, which uses qualitative research methods and techniques, is designed as a descriptive historical study based on original and primary sources. Research data were collected through document analysis. To this end, document scanning process was carried out on the research funds in Istanbul and Ankara affiliated to The Archive Centres of Directorate of State Archives of the Presidency of the Republic of Turkey. As a result of the examinations, the identified historical documents about the research subject constituted the data source of the study. The historical documents about the visits of Ahmed Kemal Effendi to some European cities were analysed through content analysis and descriptive analysis methods.

\section{Results and Discussion}

From August 1850 to April 1851, Kemal Effendi visited major European cities such as Paris, London, Brussels, Cologne, Berlin and Vienna. Kemal Effendi reported all developments to the Centre (Istanbul) during his European journey. According to a report by Kemal Effendi dated November 1, 1850, he primarily stayed in Paris for three months, provided a number of teaching tools and materials and observed the schools in Paris during eight months he was deployed for his European trip. In addition, he visited the UK and Brussels (Belgium) and made observations and investigations for educational purposes ${ }^{3}$.

In another report by Kemal Effendi ${ }^{4}$, the available globes and maps were ascertained to be quite simple to use in teaching although they had been brought from Europe to be used by Ottoman schools until that time. Furthermore, they were found to be uneven and costly when evaluated in terms of costs and gains. Moreover, since they were not translated into Turkish, it was

\footnotetext{
1 İNAL, İ. M. K. (2000). Son Asır Türk Şairleri, Vol. 2, Translated by M. Kayahan Özgül, Ankara: Atatürk Kültür Merkezi Başkanlığg Publications, p. 1150-1159; Süreyya, M. (1996). Sicil-i Osmani, Vol. 3, Translated by Nuri Akbayır, İstanbul: Tarih Vakfı Yurt Publications, p. 880-881.

23 July 1850. BOA (The Archive Centres of Directorate of State Archives of the Presidency of the Republic of Turkey), İ.DH. 216/12698.

${ }^{3} 02$ Şubat 1851. BOA, A. MKT.MVL. 38/76; BOA, A.AMD. 32/78.

${ }^{4}$ BOA, İ.MVL. 198/6146.
} 


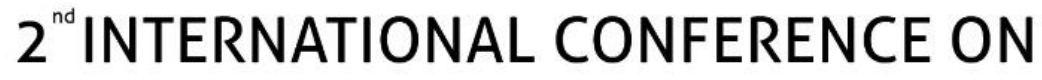 FUTURE OF TEACHING \& EDUCATION}

\section{Munich,Germany}

\section{6 - 8 December,2019}

difficult to use them during the teaching processes. Therefore, Kemal Effendi planned to produce globes and maps in Turkish to use at schools during the aforementioned trip in Paris.

As a result of the observations and investigations made by Kemal Effendi in Paris, he ordered 150 globes. It was planned to reserve one third of them, which had been started to be produced and translated into Turkish, for the Ministry of Education and the rest to be sold to those who demand ${ }^{5}$.

Kemal Effendi also dealt with some problems of Ottoman students who were in Paris for education abroad. In this regard, he was informed by the Centre that the some Ottoman students in Paris were involved in corruption and did not make the necessary efforts for their education ${ }^{6}$. Initially, it was decided to send them to Istanbul by terminating their educational process. But later, Kemal Effendi, who was in Paris at the time, was assigned to deal with the problem. Thereupon, Kemal Efendi made the necessary inquisition and reported to the Centre ${ }^{7}$. Based on the aspects stated in the report by Kemal Efendi, it was decided that the educational process of these students would not be interrupted until the end of the semester and that their debts would be paid by the State.

After conducting investigations in Paris, London and Brussels, Kemal Efendi's trip was extended by two months and he was allocated an additional allowance to carry out the necessary investigations in other European cities. ${ }^{8}$

Kemal Efendi then moved from Paris to Brussels on March 5, 1851. It was his second visit to Brussels, where he stayed for 5-6 days. During his stay in Brussels, he held several meetings in line with his duty. After leaving, he stayed one day in Cologne and moved to Berlin ${ }^{9}$. He arrived in Berlin on March 14, 1851 and met with Karacabeyzade Kostaki Bey, who was the Ottoman-Berlin ambassador. Through Kostaki Bey, he met with mentors of the Ministers of Foreign Affairs and Education of Germany and conducted observations and inspections at various educational institutions in Berlin for three to four days ${ }^{10}$.

Subsequently, Kemal Effendi, in his report of March 22, $1851^{11}$, stated that he would travel to Prussia and meet with the Prussian King after his visit to Berlin. He added that he would move to Vienna as the last destination in his trip, make observations and inspections in various educational institutions for 5-10 days and then return to Istanbul with the end of the travelling period. From an official letter dated April 24, 1851, which was sent to Istanbul from the Ottoman-Trieste consulate ${ }^{12}$, it seems that Kemal Effendi, who had arrived in Trieste, completed his Europe journey and was in a way of home.

\footnotetext{
${ }^{5}$ BOA, A. MKT.MVL. 38/76.

${ }^{6}$ BOA, İ.HR., 3500 .

${ }^{7}$ BOA, HR.TO. 36/9; BOA, İ.HR.75/3658.

${ }^{8}$ BOA, A. MKT.MVL. 38/76; BOA, A.AMD. 32/78.

${ }^{9}$ BOA, HR.TO.28/53.

${ }^{10}$ BOA, HR.MKT. 37/99.

${ }^{11}$ BOA, HR.MKT. 37/99.

12 BOA, HR.TO. 317/20.
} 


\title{
$2^{\text {nd }}$ INTERNATIONAL CONFERENCE ON FUTURE OF TEACHING \& EDUCATION
}

\section{Munich,Germany}

\author{
6 - 8 December, 2019
}

\section{Conclusion}

The modernization of the Ottoman education system was realized as a result of the increasing educational interactions with the education systems of the European states, especially during the $19^{\text {th }}$ century. In this turbulent process, the Ottoman Empire had educational interactions with many European states. Although this interaction had many dimensions, statesmen and intellectuals who were sent to Europe for various purposes played an important role. In this context, Ahmed Kemal Effendi/Pasha, one of the reformists and modernist bureaucrats of the Ottoman Tanzimat Era, was a pioneer in the implementation of modern education policies and practices with the tasks he had undertaken in the upper stages of the Ottoman education administration.

As reflected in the findings of this research, Kemal Effendi traveled to Europe from August 1850 to April 1851 and made educational observations and inspections in the cities such as Paris, London, Brussels, Cologne, Berlin and Vienna. By transferring the knowledge and experiences he gained abroad to his country, he initiated significant practices towards the modernization of education in the Ottoman Empire. Kemal Effendi's course materials, purchased from Paris, began to be used in newly established secondary schools, called as Rüştiye. It can actually be considered as the first implementation of modernization in Ottoman educational technologies. In the following period, the transformation in instructional technologies continued.

As inspector general of public instruction, Kemal Efendi's observing and inspecting on site the system implemented in schools of Europe is important in terms of providing a modern perspective to the Ottoman education reforms that were realized during the subsequent periods. In this vein, Kemal Effendi not only pioneered the first applications for the introduction of modernity into Ottoman education in the $1850 \mathrm{~s}$, but also tried to transform the aforementioned educational reforms into a permanent order and policy during the top management he was appointed in education. Therefore, the effect of Ahmed Kemal Pasha's investigations related to the European education systems on the Ottoman education system proceeded as a historical phenomenon in the consecutive periods.

\section{Acknowledgment}

This research is part of an ongoing doctoral dissertation in Gaziantep University, under the direction of Assoc. Prof. Dr. Ayhan Doğan.

\section{References}

[1] BOA (The Archive Centres of Directorate of State Archives of the Presidency of the Republic of Turkey), A. MKT.MVL. 38/76;

[2] BOA (The Archive Centres of Directorate of State Archives of the Presidency of the Republic of Turkey), A.AMD. 32/78.

[3] BOA (The Archive Centres of Directorate of State Archives of the Presidency of the Republic of Turkey), HR.MKT. 37/99 


\section{$2^{\text {nd }}$ INTERNATIONAL CONFERENCE ON FUTURE OF TEACHING \& EDUCATION}

\section{Munich,Germany}

\section{6 - 8 December,2019}

[4] BOA (The Archive Centres of Directorate of State Archives of the Presidency of the Republic of Turkey), HR.TO. 36/9; 28/53; 317/20.

[5] BOA (The Archive Centres of Directorate of State Archives of the Presidency of the Republic of Turkey), İ.DH. 216/12698.

[6] BOA (The Archive Centres of Directorate of State Archives of the Presidency of the Republic of Turkey), İ.HR., 3500, İ.HR.75/3658.

[7] BOA (The Archive Centres of Directorate of State Archives of the Presidency of the Republic of Turkey), İ.MVL. 198/6146.

[8] İnal, İ. M. K. (2000). Son Asır Türk Şairleri, Vol. 2, Translated by M. Kayahan Özgül, Ankara: Atatürk Kültür Merkezi Başkanlığı Publications.

[9] Süreyya, M. (1996). Sicil-i Osmani, Vol. 3, Translated by Nuri Akbayır, İstanbul: Tarih Vakfi Yurt Publications. 